\title{
Comparative Analysis of the Internal Organizations of Domestic and Foreign Universities Based on the Perspective of "Double First-class"
}

\author{
Qiao Dan \\ University Office, Wuhan University of Technology, 122 Luoshi Road, Wuhan, Hubei, P.R. China \\ 196378749@qq.com
}

Keywords: double first-class; first-class university; internal organizations

\begin{abstract}
China's colleges and universities, speed up the establishment of high-level industry featured colleges and universities, and keep up with the pace of World-class Universities and First-class Disciplines, the setting of teaching units in domestic and foreign universities is analysed with the method of literature review and comparative analysis. By analyzing the history, setting situation and existing problems of the internal teaching units in colleges and universities at home and abroad, the direction of the reform of the institutions within the university is proposed. That is, all colleges and universities need to adhere to the basic principles of existing disciplines and fully respect the current development of disciplines; adhere to the principles of future development of the school, take the road of differentiation and specialization, and quickly occupy the high ground of the discipline; adhere to the principles of coordinating the discipline resources of the whole school and the scientific layout of the disciplines, and optimize the resource value and performance.
\end{abstract}

\section{Introduction}

With the advent of the era of knowledge, universities have gradually entered the center of society, and knowledge and high-quality talents have become the most important resources in this era. Whether there are high-level universities is the core indicator of the development level of higher education in the country. Therefore, the state regards the promotion of high-level university construction as the mainstay of higher education, and continuously strengthens the emphasis on high-level university construction. Building a World-class university has become a crucial task in our country, which concerns the problem of building an innovative country.

The first-class university is a conclusion drawn from the perspective of quality comparison. It is a university that has significant influence at home or abroad and can cultivate a large number of high-level talents, produce major scientific research results and provide high-quality social services. For Chinese universities, they should achieve the unification of "world level" and "Chinese characteristics", as well as catch up with the international academic frontier and serve the national strategic needs. This is a due measure to build a World-class University in China. Whether China can achieve the leap from a big country of higher education to a powerful country of higher education depends on whether it can cultivate high-quality talents. If the country cannot cultivate high-quality talents, it will never become a powerful country of higher education.

For a university, teaching is the most important task in all its work, while teaching and management is an inseparable whole. The management of education is the fundamental guarantee to maintain the teaching work in colleges and universities. The task of education management is to improve the unreasonable part in teaching and fundamentally improve the teaching system and teaching order. Only by constantly improving the teaching management in colleges and universities and making the teaching management closely related to the teaching practice, can the real education be realized.

\section{Literature review}

Many scholars and experts have analyzed and studied the existing problems within the university, 
and all of them are trying to find a more reasonable and efficient organizational structure to promote the development of the university. These studies will be the basis for new research.

Menati pointed out that World-class universities, also known as research universities, are regarded as the core of the world academic system. The World-class universities reflect a country's competitiveness in the era of global knowledge economy [1].

Zhang pointed out the essential needs of building World-class universities: public income based on university performance, non-government source of income, differentiation of functions of various universities, university autonomy, property ownership of colleges and universities, scientifically open competition between countries, professional certification and licensing independence, encouragement to students, independence of teacher, and incentive measures [2].

Huang believed that it is vital for policy makers and organizers to pay more attention to project's research motivation, research innovation, increasing research budgets and reducing power interventions to university departments, increasing broadband Internet access and increasing laboratory facilities to transform universities into world-class universities [3].

Wang made an in-depth study on the institution setting within the university and carefully analyzed the development and evolution process of the discipline. He believed that the starting point and the belonging point of the institution setting within the university are the development of the discipline, and the institution of the discipline development is the foundation of other institutions [4].

Chen analyzed the problems existing in the management of scientific research institutions in colleges and universities and put forward relevant countermeasures for further strengthening the construction of internal teaching and scientific research institutions in colleges and universities [5].

Zhu discussed in detail the disadvantages of the institution setting of higher vocational colleges in China and pointed out the strategies for the reform of the institution setting of higher vocational colleges [6].

Wei elaborated on the idealized college: the college has the characteristics of substantiality, autonomy and subjectivity in the setting, management and operation, which is the center of gravity of the management of colleges and universities [7].

$\mathrm{Li}$ believed that the first-class academic atmosphere is the basis for producing first-class masters and first-class faculty, and is the most important factor in achieving first-class research results and building first-class disciplines [8].

\section{Methodology}

\subsection{The current situation of the setting of teaching units in foreign universities}

The formation and operation mechanism of the teaching unit:

Currently, the top education countries in the world are the United States and the United Kingdom, and they have many universities in the top 100 of the world's universities every year. The performance of American colleges and universities is more prominent. In the top 100 universities in the world, there are two science and technology colleges and four comprehensive universities in the United States that have entered the top ten. Therefore, understanding and learning from the mature experience of American colleges and universities in the establishment of faculties is of great benefit to the reform of colleges and universities in China.

Based on the analysis of the institute setting of the six world famous universities and colleges above, it is found that the number of institutes is relatively small. Among them, 5 universities have set up 8 or less (including 8) schools, and only Harvard has 13 schools. And the schools of these universities are basically set up based on subject categories or set up according to subject groups. Each school has a large capacity of subjects, which can cover more than ten or even twenty or thirty subjects under the same subject category at the same time. 
Table 1 Institute setting of six colleges and universities in the United States ranked among the Top100 universities in the world

\begin{tabular}{|c|c|c|}
\hline University & $\begin{array}{l}\text { School } \\
\text { number }\end{array}$ & Institute \\
\hline $\begin{array}{l}\text { California } \\
\text { Institute } \\
\text { Technology } \\
\text { (Caltech) }\end{array}$ & 7 & $\begin{array}{l}\text { School of Biological Sciences, School of Engineering \& Applied } \\
\text { Science, School of Chemistry and Chemical Engineering, School of } \\
\text { Geology and Planetary Sciences, School of Physics, School of } \\
\text { Mathematics and Astronomy, School of Humanities and Social } \\
\text { Sciences }\end{array}$ \\
\hline $\begin{array}{l}\text { Stanford } \\
\text { University }\end{array}$ & 7 & $\begin{array}{l}\text { School of Humanities and Sciences, School of Earth Sciences, School } \\
\text { of Engineering, School of Medicine, School of Law, School of } \\
\text { Commerce, School of Education }\end{array}$ \\
\hline $\begin{array}{l}\text { Massachusetts } \\
\text { Institute of } \\
\text { Technology } \\
\text { (MIT) }\end{array}$ & 6 & $\begin{array}{l}\text { School of Architecture and Urban Planning, School of Engineering, } \\
\text { School of Humanities and Social Sciences, Alfred p. Sloan school of } \\
\text { management, School of Science, Vitek Institute of Health Science and } \\
\text { Technology }\end{array}$ \\
\hline $\begin{array}{l}\text { Harvard } \\
\text { University }\end{array}$ & 13 & $\begin{array}{l}\text { Two undergraduate colleges, that is, Harvard College and Radcliffe } \\
\text { College; eleven graduate schools, that is, School of Arts and Sciences, } \\
\text { School of Business Administration, Kennedy school of management, } \\
\text { School of Design, School of Education, School of Law, Divinity } \\
\text { School, School of Dentistry, School of Public Health and University } \\
\text { Extension Division }\end{array}$ \\
\hline $\begin{array}{l}\text { Princeton } \\
\text { University }\end{array}$ & 4 & $\begin{array}{l}\text { Divided into the Department of Undergraduate and Graduate Schools: } \\
\text { The College of New Jersey, School of Engineering and Applied } \\
\text { Science, School of Architecture and Urban Design, Wilson School of } \\
\text { Public and International Affairs }\end{array}$ \\
\hline $\begin{array}{l}\text { University } \\
\text { Chicago }\end{array}$ & 8 & $\begin{array}{l}\text { Undergraduate School, Graduate School (Department of Biological } \\
\text { Science, Department of Anthropology, Department of Science, } \\
\text { Department of Social Science), School of Medicine, Booth School of } \\
\text { Business, School of Law, Divinity School, School of Public Policy, } \\
\text { and School of Social Service Administration }\end{array}$ \\
\hline Total & & 45 \\
\hline Average & & 7.5 \\
\hline
\end{tabular}

Problems existing in the setting of teaching units:

It can be seen from the above-mentioned settings of teaching units in foreign university that most schools are set based on subject categories or set according to subject groups. This setting is conducive to interdisciplinary and form emerging disciplines. With the continuous development of the Internet, traditional learning, education, assessment and curriculum setting are undergoing changes in the education field. The future direction of basic education informatization development is to build an Internet platform, cultivate cognitive thinking that combines human and computer, and strengthen collaboration with computers and the Internet. Only in this way can the vast amount of information constantly expand exponentially beyond people's cognitive ability be processed correctly. Many foreign colleges and universities are not fully aware of the rise of Internet education and need to further strengthen education teaching on the Internet.

\subsection{The current situation of the setting of teaching units in domestic universities}

The formation and operation mechanism of the teaching unit:

Based on the analysis of the institute settings of the above 10 well-known universities and colleges in China, it is found that the institute settings are mainly based on the first-level disciplines, and the number is relatively large. Only Tsinghua University has set up 16 schools, the remaining colleges and universities have 20 directly affiliated departments, and the professional division is too fine. 
Table 2 Institute setting of top 10 Chinese universities and colleges

\begin{tabular}{|l|l|}
\hline University & Institute \\
\hline Peking University & $\begin{array}{l}\text { School of department, School of Science, School of Social Sciences, School } \\
\text { of Information and Engineering, School of Medicine, and 62 directly } \\
\text { affiliated schools }\end{array}$ \\
\hline Zhejiang University & 24 schools and 81 departments \\
\hline $\begin{array}{l}\text { Tsinghua University } \\
\text { (THU) }\end{array}$ & 16 schools and 56 departments \\
\hline $\begin{array}{l}\text { Shanghai Jiaotong } \\
\text { University (SJTU) }\end{array}$ & 28 schools \\
\hline Fudan University & 29 directly affiliated schools \\
\hline $\begin{array}{l}\text { Nanjing University } \\
\text { (NJU) }\end{array}$ & 28 directly affiliated schools \\
\hline Wuhan University & 36 schools and 6 undergraduate departments \\
\hline $\begin{array}{l}\text { Sichuan University } \\
\text { (SCU) }\end{array}$ & $\begin{array}{l}30 \text { disciplinary schools, school of overseas education and } 2 \text { independent } \\
\text { schools of Jincheng and Jinjiang }\end{array}$ \\
\hline Zhongshan University & 37 schools \\
\hline Shandong University & 47 directly affiliated schools \\
\hline
\end{tabular}

Problems existing in the setting of teaching units:

Through comparison, it is found that there are still some problems in the establishment of teaching units in Chinese universities. Firstly, domestic colleges and universities have set up many schools but there is no hierarchy, as shown in figure 1 and figure 2. There is no distinction between basic disciplines and applied disciplines. The importance of basic research personnel is only superficial, which will have a great impact on the development of basic science and the subsequent development of applied science. Secondly, the subject organization within domestic universities has an obvious administrative property. It divides the work tasks of each unit according to the functional departments. The management range is narrow and the management efficiency is low, resulting in a lot of waste of people, money and things. Finally, the internal schools of domestic universities are mainly set up by the first-level disciplines, the number is too large, the level of discipline integration is not high, and the divisions of various departments and professions are too fine. There is no broad talent development platform and scientific research platform, which is not conducive to the emergence of emerging disciplines and interdisciplinary disciplines in the blank space of the profession, and it is also difficult to cultivate high-quality talents with interdisciplinary skills.

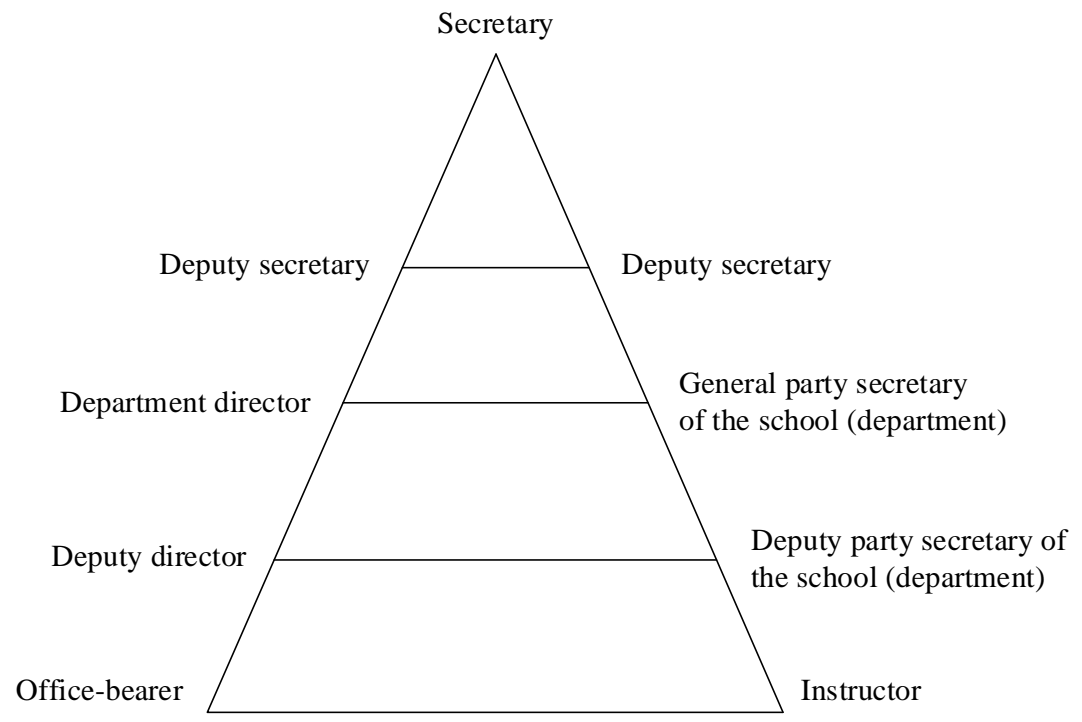

Figure. 1 Example of the management level of the party committee system 


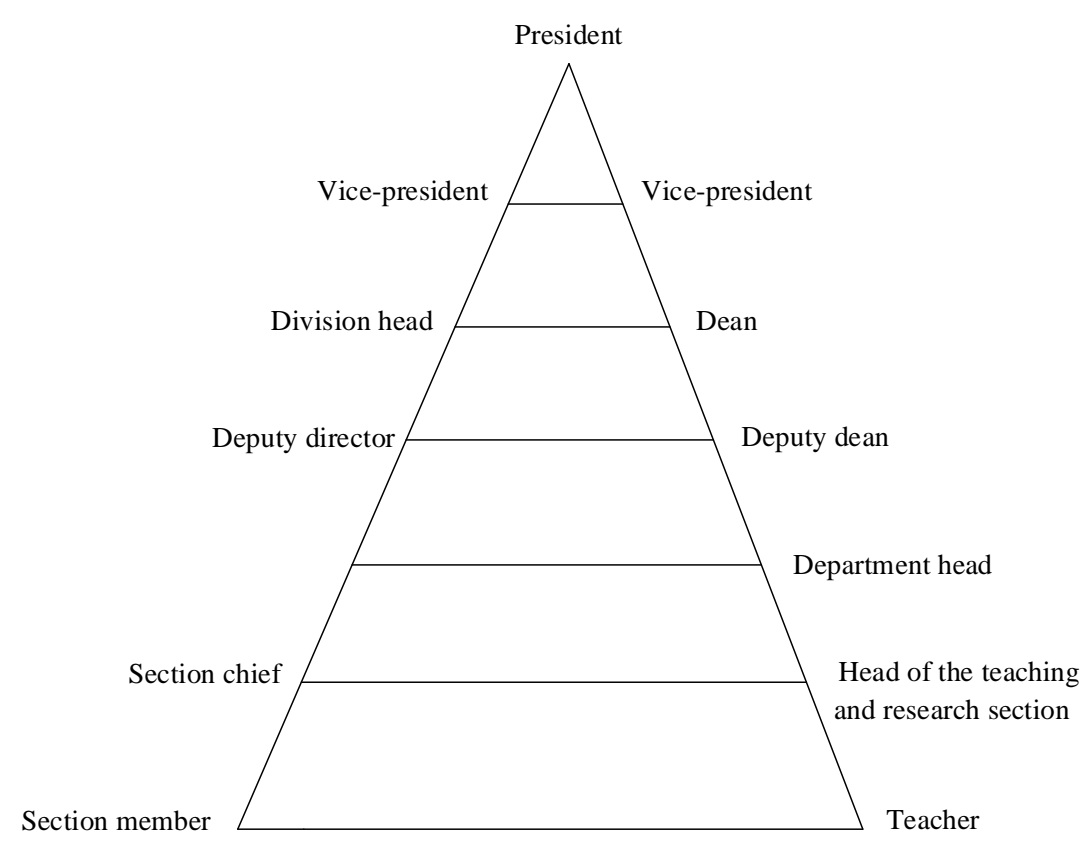

Figure. 2 Example of management level of administrative system

\section{Results and discussion}

China's construction of “double first-class” needs to focus on the specific situation of China's economic and social development while aiming at the international goal. In the construction process, it should not only meet the international and universal standards, but also meet the local and special indicators, in which the Chinese characteristics and standards should be highlighted.

The first is to innovate the organization and management mode of colleges and universities. The institutional management of universities has always been the focus of education reform in China, and the construction of "double first-class" universities is an opportunity for Chinese universities to break through the traditional administrative model. In the new organization and management, colleges and universities should make appropriate adjustments according to their own schoolrunning characteristics, scale, historical and cultural accumulation and other specific conditions. They should improve the constitution of the university and give secondary colleges more space for development.

The second is to clarify the positioning of universities. Strategic positioning includes the precise goal of university development, school type, detailed planning, etc. "Double first-class" universities have extremely high requirements on all aspects of colleges and universities. Without ambitious and precise goals and accurate development strategies, it is difficult to stand out among numerous colleges and universities.

The third is to carefully plan the development of each discipline. There is no first-class university without first-class disciplines. First-class disciplines and first-class universities complement each other. Moreover, different disciplines have different characteristics. According to the specific situation of colleges and universities and the characteristics of different subjects, it should aim at the social demand, keep close to the prospect of social development, formulate different construction standards, and promote the characteristic development of universities.

The fourth is to create a first-class teaching team. In the process of building a first-class faculty, universities should establish a scientific evaluation system, build a good teaching and research environment, strengthen teacher training and study, promote the improvement of teachers' level, and provide sufficient conditions and motivation for the development of teachers.

The fifth is to cultivate first-class talents. The state should constantly reform the departments, majors, courses and other aspects of colleges and universities, improve the professional quality and level of colleges and universities, innovate the evaluation standards of talents, strengthen the integration of teaching and practice, constantly cultivate the first-class talents, and improve the 
country’s human resources.

\section{Conclusion}

On the basis of summarizing the existing literatures, the institute setting of the teaching unit is taken as the key point of the question, the phenomena and problems of the institute setting within the university are analysed, the internal logic of setting up internal teaching units in colleges and universities is summarized and some advanced experience of setting up teaching units in world famous universities is used for reference. After analyzing the phenomena and problems in the establishment of teaching units in the development of colleges and universities in China, some strategies for the optimization of teaching units in colleges and universities are put forward. In the process of creating "Double First-class" universities, all colleges and universities need to adhere to the basic principles of existing disciplines and fully respect the current development of disciplines; adhere to the principle of future development of the school, take the road of differentiation and specialization, and quickly occupy the high ground of the discipline; adhere to the principle of coordinating the discipline resources of the whole school and the scientific layout of the disciplines, and optimize the resource value and performance. Form the overall planning, supervision, evaluation of the university as well as the school management system with colleges as the main body, stimulate the internal power and vitality of teaching and scientific research units, cultivate first-class talents, produce first-class results, and create first-class disciplines.

\section{References}

[1] Menati, W., Nazarzadeh, M., Bidel, Z., Würtz, M., Menati, R., \& Hemati, R., et al. (2016). Social and psychological predictors of initial cigarette smoking experience: a survey in male college students. Am J Mens Health, 10(1), 14-23.

[2] Zhang, L., Zhang, X., \& Xi, Y. (2017). The sociality of resources: Understanding organizational competitive advantage from a social perspective. Asia Pacific Journal of Management, 34(3), 619648.

[3] Huang, G. (2018). Research Hotspots and Trends of Domestic Corporate Social Responsibility - Visualization Analysis of Knowledge Map Based on CNKI and Citespace V. Open Journal of Business and Management, 6(04), 797.

[4] Wang, M., Morley, M. J., Cooke, F. L., Xu, J., \& Bian, H. (2018). Scholars, strategists or stakeholders? Competing rationalities and impact of performance evaluation for academic managers in Chinese universities. Asia Pacific Journal of Human Resources, 56(1), 79-101.

[5] Chen, X., \& Liu, Y. (2018). Research on the Spatial Reconstruction of University Libraries: A Case Study of Liu Xiao Ling Tong Book Pavilion of Yunnan Normal University. Libri, 68(3), 165179.

[6] Zhu, X., \& Li, J. (2018). Conceptualizing the ontology of higher education with Chinese characteristics. Educational Philosophy and Theory, 50(12), 1144-1156.

[7] Wei, J., Chen, H., \& Long, R. (2018). Determining Multi-Layer Factors That Drive the Carbon Capability of Urban Residents in Response to Climate Change: An Exploratory Qualitative Study in China. International journal of environmental research and public health, 15(8), 1607.

[8] Li, S., Chen, H., Huang, X., \& Long, R. (2018). Who Has Higher Willingness to Pay for Occupational Safety and Health?-Views from Groups with Different Public Identities and Differences in Attention. International journal of environmental research and public health, 15(8), 1667. 